\title{
Small Mammals as Carriers/Hosts of Leptospira spp. in the Western Amazon Forest
}

\author{
Luciana dos Santos Medeiros ${ }^{1 *}$, Susan Christina Braga Domingos ${ }^{1}$, \\ Maria Isabel Nogueira Di Azevedo ${ }^{2}$, Rui Carlos Peruquetti ${ }^{1}$, \\ Narianne Ferreira de Albuquerque ${ }^{1}$, Paulo Sérgio D'Andrea ${ }^{3}$, \\ André Luis de Moura Botelho ${ }^{4}$, Charle Ferreira Crisóstomo ${ }^{4}$, Anahi Souto Vieira ${ }^{2}$, \\ Gabriel Martins ${ }^{2}$, Bernardo Rodrigues Teixeira ${ }^{3}$, Filipe Anibal Carvalho-Costa ${ }^{5}$ and \\ Walter Lilenbaum ${ }^{2}$
}

\section{OPEN ACCESS}

Edited by:

Lester J. Perez,

University of Illinois at

Urbana-Champaign, United States

Reviewed by:

André Alex Grassmann, University of Connecticut Health

Center, United States

Sharon Yvette Angelina Manalo

Villanueva,

University of the Philippines

Manila, Philippines

Vanina Guernier,

USDA APHIS Veterinary Services,

United States

*Correspondence: Luciana dos Santos Medeiros lusmedeiros@yahoo.com.br

Specialty section: This article was submitted to Veterinary Infectious Diseases, a section of the journa

Frontiers in Veterinary Science

Received: 02 June 2020 Accepted: 31 August 2020 Published: 02 December 2020

Citation:

Medeiros LdS, Domingos SCB, Di Azevedo MIN, Peruquetti RC, de

Albuquerque NF, D'Andrea PS, Botelho ALM, Crisóstomo CF, Vieira AS, Martins G, Teixeira BR, Carvalho-Costa FA and Lilenbaum W (2020) Small Mammals as Carriers/Hosts of Leptospira spp. in the Western Amazon Forest.

Front. Vet. Sci. 7:569004 doi: 10.3389/fvets.2020.569004
${ }^{1}$ Laboratório de Microbiologia e Imunologia Veterinária, Universidade Federal do Acre, Rio Branco, Brazil, ${ }^{2}$ Laboratório de Bacteriologia Veterinária, Universidade Federal Fluminense, Niterói, Brazil, ${ }^{3}$ Laboratório de Biologia e Parasitologia de Mamíferos Silvestres Reservatórios, IOC, Fiocruz, Rio de Janeiro, Brazil, ${ }^{4}$ Instituto Federal de Educação, Ciência e Tecnologia do Acre, Rio Branco, Brazil, ${ }^{5}$ Laboratório de Epidemiologia e Sistemática Molecular, IOC, Fiocruz, Rio de Janeiro, Brazil

Leptospira is a bacteria that causes leptospirosis and is transmitted through water, soil, or mud that is contaminated by the urine of infected animals. Although it is mainly associated with the urban environment, Leptospires also circulate in rural and wild environments. This study aimed to investigate the role of small mammals in leptospirosis epidemiology in the western Amazon, Brazil. In total, 103 animals from 23 species belonging to the orders Didelphimorphia and Rodentia were captured. Blood, kidney, and urine samples were collected and Microscopic Agglutination Test (MAT), lipL32 PCR, secY sequencing, and culturing were conducted. MAT was reactive on 1/15 sera, and no bacterial isolate was obtained. PCR yielded $44.7 \%$ positive samples from 16 species. Twenty samples were genetically characterized and identified as $L$. interrogans $(n=12)$, L. noguchii $(n=4)$, and $L$. santarosai $(n=4)$. No statistical association was found between the prevalence of infection by Leptospira spp. in small mammals within carrier/hosts species, orders, study area, and forest strata. Our results indicate a high prevalence of pathogenic Leptospira spp. in several rodent and marsupial species and report the first evidence of Leptospira spp. carrier/hosts in the Brazilian Western Amazon.

Keywords: marsupial, small mammal, Amazon, wild rodent, sylvatic leptospirosis

\section{INTRODUCTION}

Leptospirosis is a zoonotic infectious disease caused by the bacteria from the Leptospira genus (1) and transmitted through water, soil, or mud contaminated by the urine of infected animals. Although it is mainly reported in the urban environment, leptospirosis also circulates in rural and wild environments, with a wide variety of mammal species acting as carrier/hosts of the bacterium (2).

The Amazonian biome has the ideal conditions for maintaining and disseminating Leptospira spp. The high humidity and temperature along with the high diversity of mammals and potential renal carriers of the bacteria, creates a scenario that exposes the animals to different strains of Leptospira $(3,4)$. Besides the importance of small mammals in the maintenance of Leptospira spp. 
in the wild and in the transmission to humans, the possibility of transmission between wild and domestic animals has been a major concern among conservationists and livestock authorities in many areas, especially in the Amazon (5-7). The emergence of zoonosis can greatly impact the abundance of some carrier/host populations, in some extreme cases leading to local extinctions (8).

Every mammal is a potential renal carrier of leptospires. Rodents have been described as the most essential maintenance/amplifier reservoirs in nature for several pathogenic Leptospira (9, 10). In Brazil, marsupials from the eastern Amazon (11), semi-arid regions (12), and the Atlantic Forest biome $(13,14)$ have also been reported with antibodies against Leptospira spp. The first report of Leptospira isolation in samples of Didelphis albiventris was from southern Brazil. These findings suggest marsupials may serve as important transmission reservoirs of pathogenic Leptospira spp. (15). Despite this, little is known about the role of wild small mammals as Leptospira carrier/hosts in the Amazon forest. Therefore, the objective of this study was to identify Leptospira infection in wild small mammals (rodents and marsupials) and investigate predictor variables related to infection in these animals in the Western Amazon, Brazil.

\section{MATERIALS AND METHODS}

\section{Study Design}

The following licenses were used to conduct the study: permanent license to collect zoological material number 13373 (SISBIO-ICMBIO) and CEUA LW-39/14 license (Ethics Committee on Animal Use, FIOCRUZ). The studied areas were forests in the state of Acre, Brazil, western Amazon on Acre river basin, and represented different levels of conservation and land use (Figure 1). These areas included: (1) Floresta do Seringal Cachoeira (FSC) $\left(10^{\circ} 49^{\prime} \mathrm{S}, 68^{\circ} 21^{\prime} \mathrm{W}\right)$, in the municipality of Xapuri, a continuous and conserved primary forest with 24,200 ha, a medium anthropic impact and land use for ecotourism and traditional activities of latex and castanha-doBrasil extractions; (2) Reserva Florestal Humaitá (RFH) $\left(9^{\circ} 43^{\prime} \mathrm{S}\right.$, $67^{\circ} 48^{\prime} \mathrm{W}$ ), in the municipality of Porto Acre, is a wide fragment of $\sim 2,000$ ha of primary and secondary rain forest, submitted to moderate anthropic action, surrounded by farms, roads and a large river. This area belongs to the Federal University of Acre (UFAC) and is a preserved area designated for research; (3) Floresta Experimental Catuaba (FEC) $\left(10^{\circ} 04^{\prime} \mathrm{S}, 67^{\circ} 37^{\prime} \mathrm{W}\right)$, in the municipality of Senador Guiomard, comprising 900 ha of primary and secondary rain forest. This farm is used for research

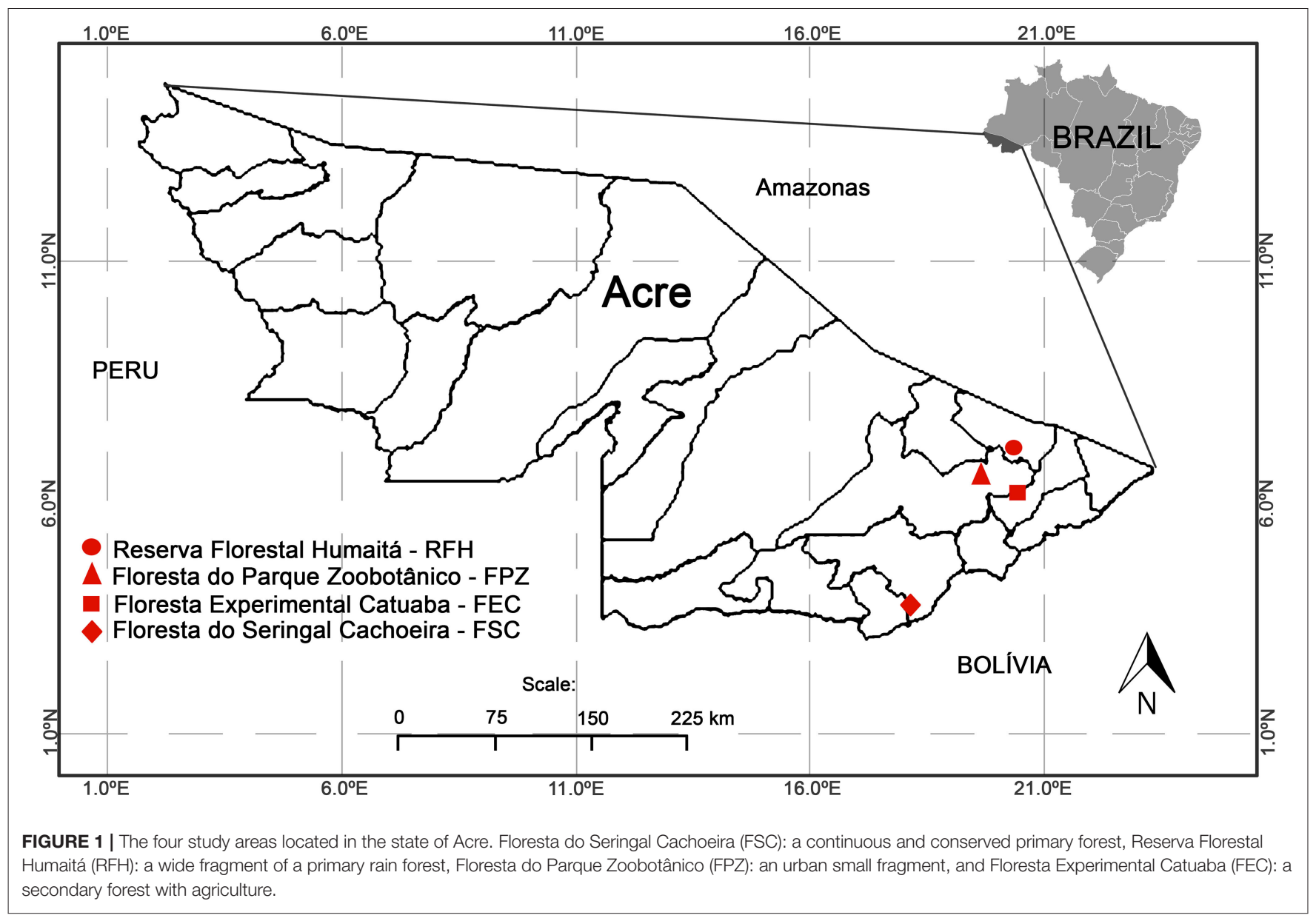


activities and also belongs to UFAC; and (4) Floresta do Parque Zoobotânico (FPZ) $\left(9^{\circ} 57^{\prime} \mathrm{S}, 67^{\circ} 52^{\prime} \mathrm{W}\right)$, in the municipality of Rio Branco, an intense anthropized small fragment of approximately 140 ha in different succession stages. It is an urban park located on the UFAC campus, with land use destined to activities such as trekking, research, and recreation.

The field expeditions to capture small mammals and collect biological samples were conducted in the rainy seasons, between November and December 2015, at the RFH, FPZ, and FSC, and in FEC in December 2016.

\section{Animal Capture}

Trapping was conducted over five consecutive nights. In each study area, the animals were captured with live traps, Sherman ${ }^{\circledR}$ $(30 \times 8 \times 9 \mathrm{~cm})$ and Tomahawk ${ }^{\circledR}(40 \times 12 \times 12 \mathrm{~cm})$, in five to ten linear transects with 15 trapping stations each. Sampling was conducted at three forest strata-soil level, understory (at a height of $2 \mathrm{~m}$ ), and canopy $(15 \mathrm{~m})$. At the end of each transect, four pitfalls were installed, with a volume of $60 \mathrm{~L}$. The bait used was a mixture of bacon, oat, banana, and peanut butter. The captured animals were transported to a field laboratory base, where they were anesthetized and euthanized following the procedures reported previously (16). Blood samples were collected by cardiac puncture. Immediately after euthanasia, the urinary bladder and kidneys were exposed, and urine and kidney fragments were collected using sterile instruments. The small mammals were identified by external and cranial morphology, karyotyping, and DNA sequencing of cytochrome b gene $(17,18)$. Specimens were deposited in the mammal collection of the Laboratório de Biologia e Parasitologia de Mamíferos Reservatórios Silvestres, Instituto Oswaldo Cruz (tagged as LBCE), Rio de Janeiro, Brazil.

\section{Bacteriological Procedures}

Individual urine samples were processed immediately in a mobile laboratory. Three to five drops of urine were inoculated to three different culture mediums: $5 \mathrm{~mL}$ of liquid EMJH medium (Difco, BD, Franklin Lakes, NJ, USA), $5 \mathrm{~mL}$ of semisolid Fletcher medium (Difco, BD, Franklin Lakes, NJ, USA), and $5 \mathrm{~mL}$ of liquid EMJH medium supplemented with an antibiotic cocktail named STAFF (19). Kidney fragment samples were macerated into $\mathrm{EMJH}$ using a $5 \mathrm{~mL}$ syringe. After inoculation, the tubes were maintained at room temperature and sent to the Reference Laboratory on Rio de Janeiro after 5 days due to Biosafety standards (4,000 km away from the initial collection site). There, tubes were incubated at $28^{\circ} \mathrm{C}$ and evaluated weekly for 4 months using dark-field optical microscopy. If contamination occurred, the liquid cultures were filtered or once again transferred to the EMJH and STAFF.

\section{Serology}

To detect anti-Leptospira antibodies, we conducted the MAT according to World Organization for Animal Health standards (20). Strains related to 22 serogroups were used as antigens, using the highest titer obtained to identify the infecting serogroup. Animals were considered seroreactive when titration was $\geq 50$, as carrier/host animals tend to present low titers (21).

\section{PCR}

DNA was extracted from all individual kidney samples using the DNeasy ${ }^{\circledR}$ Blood \& Tissue Kit (QIAamp, Qiagen, France) as recommended by the manufacturer. First, PCR was conducted using primers targeting a short region of the lipL32 gene (241 bp), reported to be present only in pathogenic leptospires (LipL3245F: 5' -AAG CAT TAC CGC TTG TGG TG-3' and LipL32-286R: $5^{\prime}$-GAA CTC CCA TTT CAG CGA TT-3') (21). Second, lipL32 positive samples were subjected to a nested PCR targeting a partial region of $\sec \mathrm{Y}$ gene. An initial reaction targeting a 549 bp region was conducted using the primers secY_outer_F $\left(5^{\prime}\right.$-ATGCCGATCATTTTTGCTTC- $\left.3^{\prime}\right)$ and secY_outer_R (5'- CCGTCCCTTAATTTTAGACTTCTTC- ${ }^{\prime}$ ). Finally, amplicons were included in a second reaction using the primers secY_inner_F (5'-CCTCAGACGATTATTCAATGGTTATC-3') and secY_inner_R (5'- AGAAGAGAAGTTCCACCGAATG-3') (Mathieu Picardeau, personal communication, November $27,2019)$, providing an expected amplicon of $410 \mathrm{bp}$. In all reactions, for each set of samples, ultrapure water was used as negative control, while $10 \mathrm{fg}$ of DNA extracted from Leptospira interrogans serovar Copenhageni (Fiocruz L1-130) was used as positive control. PCR products were analyzed by gel electrophoresis in 1.5-2\% agarose and visualized under UV light, after GelRed ${ }^{\circledR}$ staining.

\section{Sequencing and Phylogenetic Analysis}

The secY amplicons were directly sequenced using the Big Dye Terminator v. 3.1 Cycle Sequencing Ready Reaction Kit (Applied Biosystems) in a 3100 Automated DNA Sequencer according to the manufacturer's instructions. The nucleotide sequences were deposited in GenBank under accession numbers MT361666-MT361685. Phylogenetic analysis was accomplished using Pairwise/Blast/NCBI, SeqMan v. 7.0, ClustalW v. 1.35 (22) and BioEdit v. 7.0.1 (23) software for editing and sequence analysis. A maximum likelihood (ML) tree was constructed using the Tamura-Nei model with the gamma distribution $(\mathrm{TN}+\mathrm{G})$ in MEGA X software (24), as it was determined to be the best-fitting model of DNA substitution using the Bayesian information criterion. Information about sequences used for phylogenetic analysis is shown in the Supplementary Material.

\section{Statistics}

We calculated the prevalence of infection by Leptospira sp., considering mammal carrier/host orders (rodents and marsupials), localities (FSC, RFH, FPZ, and FEC), forest strata (soil, understory, or canopy) and species. Prevalence of infection represents the proportion of PCR positive carrier/hosts by the total number of analyzed individuals.

Considering differences in conservation status among the study areas and differences among small mammal species in terms of their habits and habitat use, we tested the influence of carrier/host species, carrier/host orders, study area, and forest strata on the prevalence of infection by Leptospira spp. using generalized linear models (GLM). Best models were chosen using the corrected Akaike information criterion (AICc), where the suitable models presented Delta AICc $\leq 2$. The GLM analysis followed a binomial distribution. The analyses were performed 

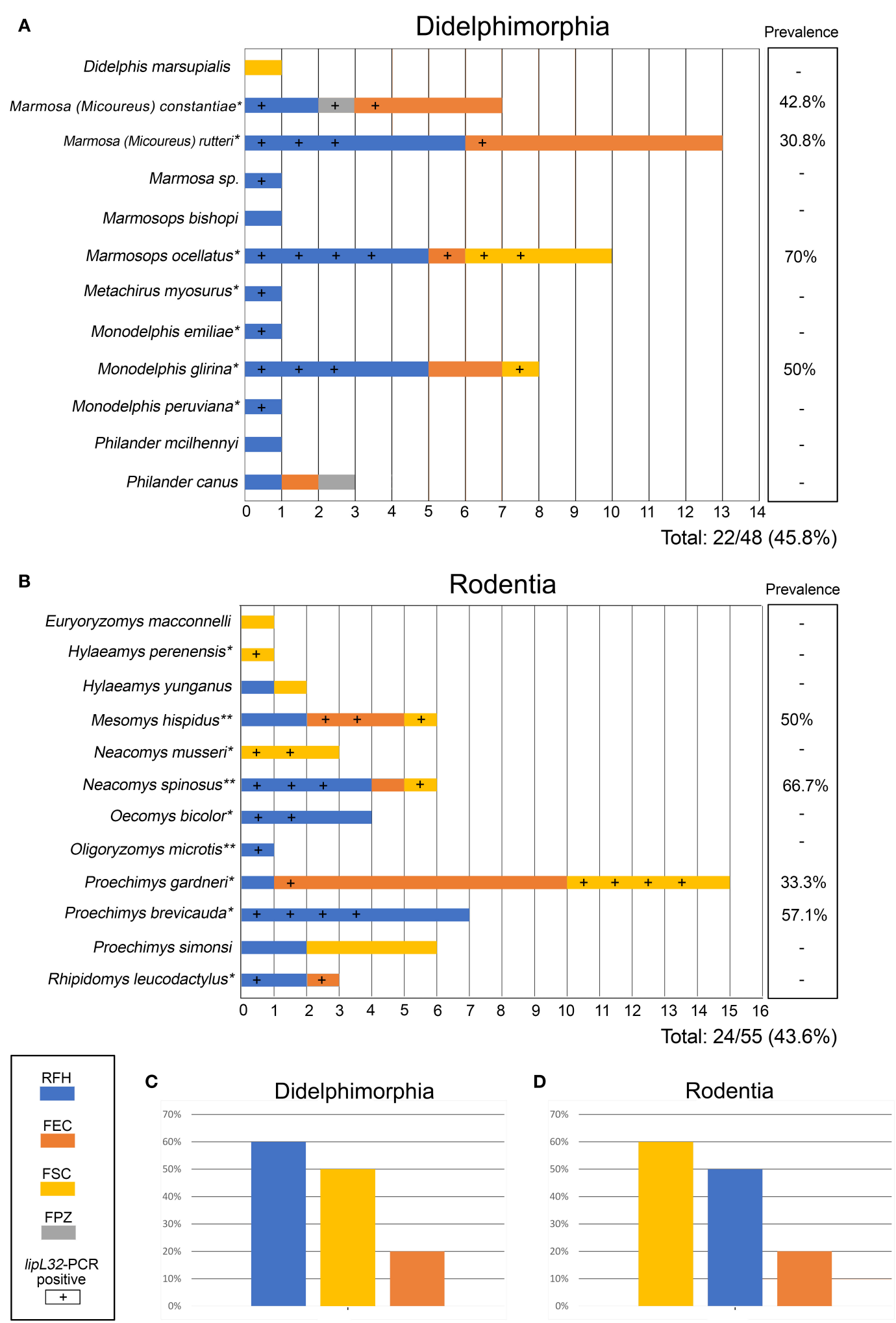

FIGURE 2 | Small mammals (A: Didelphimorphia; B: Rodentia) included in the present study according to study area (shown by different colors as indicated in the figure). Samples positive for pathogenic Leptospira, detected by lipL32 gene amplification, are indicated by a (+) sign. Columns at right show prevelance values for each host. Pathogenic Leptospira prevalence on Didelphimorphia (C) and Rodentia (D) of each collection site are also presented. *Species with first Leptospira DNA detection. ${ }^{*}$ Species already described as carrier hosts of Leptospira by Bunnell at al. (29) and Cortez et al. (30). Species for which all samples were negative for Leptospira have no asterisk. Study areas located in the state of Acre: Floresta do Seringal Cachoeira (FSC), Reserva Florestal Humaitá (RFH), Floresta do Parque Zoobotânico (PPZ), and Floresta Experimental Catuaba (FEC). 
with $\mathrm{R}$ version 3.4 .2 (25) using the vegan package (26). We also tested differences in Leptospira infection between two rodent families (Cricetidae and Echimyidae), with different evolutionary histories, using a chi-square test.

\section{RESULTS}

We analyzed 103 animals, including 55 wild rodents and 48 marsupials, belonging to 23 species (Figures 2A,B). Of 15 serum samples subjected to MAT, only one (6.6\%) was positive, a sample from the marsupial Marmosa (Micoureus) rutteri that was reactive to two L. interrogans serogroups (Australis and Autumnalis) at a titer of 1:100 each. All kidney culture attempts were negative. The most important result was the high prevalence (44.7\%) of the lipL32 gene confirmed by PCR. Of the 15 sera submitted to MAT, six were lipL32 positive and nine were negative by PCR (including the only positive in MAT). We detected leptospiral DNA in kidney samples from carrier/hosts representing 16 species ( $n=46 / 103$, overall prevalence of $44.7 \%$ ) in all four study areas investigated. Of the 23 mammalian carrier/host species studied, 16 had at least one leptospiral DNApositive specimen (Figures 2A,B). In the carrier/host Marmosops ocellatus, Leptospira was found in $7 / 10$ (70\%) specimens, the highest prevalence in marsupials (Figure 2A). In rodents, Neacomys spinosus showed the highest percentage of lipL32-PCR positives (4/6, 66.7\%) (Figure 2B).

The prevalence by study area was $12 / 23$ (52.2\%) in FSC, $26 / 49$ (53.1\%) in RFH, $1 / 2$ (50\%) in FPZ and $7 / 29$ (24.1\%) in FEC. Considering mammal orders, 22/48 (45.8\%) marsupials and 24/55 (43.6\%) rodents were PCR-positive. The prevalence by forest strata were 13/29 (44.8\%) in canopy, 26/59 (44.1\%) in soil and 6/14 (42.9\%) in understory. The prevalences for each species are shown in Figures $\mathbf{2 A}, \mathbf{B}$, and prevalances according to collection site are show on Figure 2C (marsupials) and Figure 2D (rodents).

Considering only the PCR positive samples, 12/46 (26.1\%) were positive in FSC, 26/46 (56.5\%) in RFH, 1/46(2.2\%) in FPZ, and $7 / 46$ (15.2\%) in FEC. Among mammal orders, 22/46 (47.8\%) marsupials and 24/46 (52.2\%) rodents were PCR positive. Also, considering forest strata, 13/45 (28.9\%) in canopy, 26/45 (57.8\%) in soil, and 6/45 (13.3\%) in understory were PCR positive.

According to GLM analyses, the model with study area was suitable; however, the null model was also suitable, indicating no relation between the prevalence of infection by Leptospira sp. in small mammals considering the studied variables (Table 2). There were no differences in Leptospira infection between Cricetidae $(12 / 21=57.1 \%)$ and Echimyidae $(12 / 34=35.3 \%)\left(\chi^{2}\right.$ $=2.52, p=0.1124, \mathrm{df}=1)$.

DNA from 20 samples representing 13 carrier mammalian species was amplified and sequenced using the secY genetic marker (410 bp), providing a species-specific identification of leptospires. In three samples, it was not possible to perform phylogenetic analysis due to low sequence quality. Pairwise/Blast/NCBI comparisons with the GenBank secY gene dataset identified them as L. interrogans $(n=12)$, L. noguchii $(n=4)$ and L. santarosai $(n=4)$ (Table 1$)$. Phylogenetic
TABLE 1 | Pathogenic Leptospira genetically identified through secY gene sequencing in small mammals of the western Amazon.

\begin{tabular}{|c|c|c|c|}
\hline Carrier/Host & $\begin{array}{l}\text { Leptospira } \\
\text { species }\end{array}$ & $\begin{array}{l}\text { Collection } \\
\text { Site }\end{array}$ & $\begin{array}{c}\text { Sample ID } \\
\text { (LBCE) }\end{array}$ \\
\hline \multicolumn{4}{|l|}{ DIDELPHIMORPHIA } \\
\hline \multirow[t]{2}{*}{ Marmosa (micoureus) constantiae } & L. interrogans & $\mathrm{RFH}$ & 19802 \\
\hline & L. noguchii & FPZ & 19850 \\
\hline Marmosa (Micoureus) rutteri & L. interrogans & $\mathrm{RFH}$ & 19826 \\
\hline \multirow[t]{2}{*}{ Marmosops ocellatus } & L. interrogans & $\mathrm{RFH}$ & 19804 \\
\hline & L. interrogans & FEC & 18063 \\
\hline Marmosops ocellatus & L. santarosai & FSC & 19866 \\
\hline Metachirus myosurus & L. santarosai & FSC & 19828 \\
\hline \multirow[t]{2}{*}{ Monodelphis glirina } & L. interrogans & $\mathrm{RFH}$ & 19799 \\
\hline & L. santarosai & FSC & 19871 \\
\hline Monodelphis peruviana & L. santarosai & $\mathrm{RFH}$ & 19823 \\
\hline \multicolumn{4}{|l|}{ RODENTIA } \\
\hline Mesomys hispidus & L. noguchii & FSC & 19861 \\
\hline \multirow[t]{3}{*}{ Neacomys spinosus } & L. interrogans & $\mathrm{RFH}$ & 19818 \\
\hline & L. interrogans & $\mathrm{RFH}$ & 19845 \\
\hline & L. interrogans & FSC & 19875 \\
\hline Neacomys musseri & L. interrogans & FSC & 19881 \\
\hline Oligoryzomys microtis & L. interrogans & $\mathrm{RFH}$ & 19817 \\
\hline Proechimys gardneri & L. noguchii & FSC & 19882 \\
\hline Proechimys gardneri & L. interrogans & FEC & 18052 \\
\hline Proechimys brevicauda & L. interrogans & $\mathrm{RFH}$ & 19812 \\
\hline Rhipidomys leucodactylus & L. noguchii & $\mathrm{RFH}$ & 19819 \\
\hline
\end{tabular}

Study areas located in the state of Acre: FSC, Floresta do Seringal Cachoeira; RFH, Reserva Florestal Humaitá; PPZ, Floresta do Parque Zoobotânico; FEC, Floresta Experimental Catuaba.

analysis based on $\mathrm{ML} \mathrm{TN}+\mathrm{G}$ tree including $\sec \mathrm{Y}$ sequences from different carrier/hosts confirmed species identification (Figure 3). Sequence data included in phylogenetic analysis are shown in the Supplementary Material. Sequences of $L$. interrogans from the present study clustered together with sequences of Leptospira isolated from small mammals but also isolated from humans, swine, and dogs from different geographical locations (Figure 3) with high support value (98\%). Two main L. noguchii clusters are observed, with all sequences from the present study grouping with high support value (99\%) with sequences of Leptospira isolated from swine and opossum, from China and Peru, respectively, and distant from sequences from other carrier/hosts (Figure 3). A main cluster well-supported (98\%) was observed with L. santarosai sequences from the present study and those from different carrier/hosts and geographical locations, including small mammals, humans, swine, and capybara, all from Americas (Figure 3).

\section{DISCUSSION}

To our knowledge, this is the first study that investigated the leptospiral infection in small mammals in the Brazilian Western Amazon forest. Only one sample (6.6\%), originating from the marsupial Marmosa (Micoureus) rutteri, was reactive against two L. interrogans serogroups (Australis and Autumnalis) with 


Armadillo

\begin{tabular}{|l|}
\hline Asia \\
Central America \\
$\square$ Europe \\
$\square$ North America \\
$\square$ Oceania \\
South America \\
\hline
\end{tabular}

KY357118 L. interrogans KY357127 L. interrogans MG932792 L. interrogans 슬 EU357988 L. interrogans EU357996 L. interrogans 19817 상 19881 달 19818 CP039283 L. interrogans MH683048 L. interrogans MG932797 L. interrogans KY357115 L. interrogans ip KY357100 L. interrogans KY357071 L. interrogans ơ 19875 19826 $\underline{18063}$

CP047496 L. interrogans 19802 18052

98 19804 $\underline{19845}$ 19812 19799

EU358049 L. interrogans

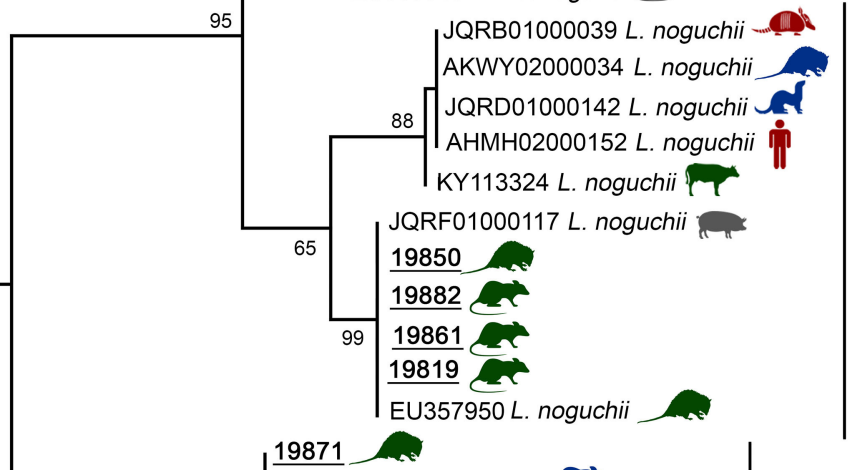

L. noguchii

EU358016 L. santarosai

98

KC492823 L. santarosai

EU358063 L. santarosai

EU357959 L. santarosai

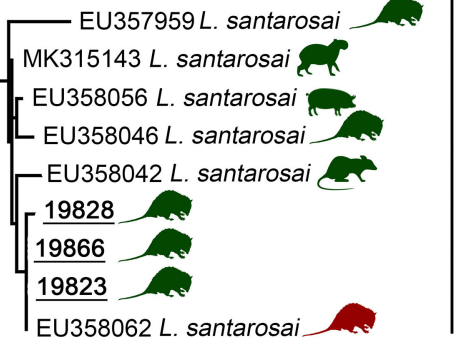

L. santarosai

\section{L. interrogans}

NC010602 L.biflexa str Patoc sv Patoc

$$
0.050
$$

FIGURE 3 | Maximum likelihood phylogenetic tree inferred from partial secY gene sequences (410 bp) of L. interrogans, $L$. noguchii, and $L$. santarosai from this study (bold and underlined) and GenBank sequences from other carrier/hosts (accession numbers are shown). Hosts are indicated by vectors and geographical locations by colors, as indicated in the figure. Numbers at nodes are bootstrap values $>50 \%$. Leptospira biflexa strain "Patoc" is the outgroup taxa. 
titers of 1:100 each. A limitation of this study was the small number of samples submitted to MAT, as obtaining sera from wild animals is not a trivial procedure. However, as reservoirs tend to show a seronegative response (27), the focus of this study was the identification of carriers/hosts by bacterial isolation and molecular techniques.

No bacterial isolate was obtained, possibly due to the expected low sensitivity of this technique. It is known that bacterial culturing of leptospires is fastidious, laborious, and difficult to perform (28). Additionally, the transport of samples from the field Laboratory on Acre State to the Reference Laboratory on Rio de Janeiro State delayed the filtration and reseeding of the samples, and consequently impaired bacterial isolation. Thus, the use of molecular techniques contributed for improving sensitivity of leptospiral detection, providing a broader understanding of the potential significance of infection.

We could identify, by PCR, seven Didelphimorphia and nine Rodentia species that could act as carriers of leptospires in the Amazon region. Our findings show, 13 new carrier/hosts (Figures 2A,B). Additionally, three species (Mesomys hispidus, Neacomys spinosus and Oligoryzomys microtis) were already described as leptospiral carriers in the Peruvian Amazon $(29,30)$ but described for the first time in the Brazilian region. Although the role of wild animals in the leptospirosis transmission cycle is unclear, the high diversity of carrier/host species found and the lack of correlation between a specific taxonomic level and a forest stratum with leptospiral infection suggest wide dissemination of the bacteria in those environments. Some studies found a higher occurrence of Leptospira infection in specific species of small mammals or a specific habitat/locality (9, 31). In our study, although we had observed differences in prevalence among study areas, the GLM model had no differences in relation to the null model (Table 2). Thus, there was no clear evidence of influence of those study areas with different land use and levels of conservation on the Leptospira prevalence.

Samples from the present study clustered in highly supported clades with $L$. interrogans, L. noguchii, and L. santarosai. Interestingly, sequences from the present study were similar $(>98 \%)$ to sequences identified in rodents and marsupials from different locations, including all continents (Figure 3). Moreover, while $L$. noguchii sequences were closest to each other, forming a distinct clade almost exclusively with sequences from South America. L. interrogans and L. santarosai sequences were closely related to sequences from other carrier/hosts from different geographical locations, including dogs and humans. This reinforces that these strains are widespread geographically and between carrier/host species.

From the epidemiological perspective, the identification of the animal species that may act as carriers/hosts is crucial since each species has a particular habitat use and geographic distribution. Thus, our data comprise 16 new mammalian species, described in Table 1, that can be carrier/hosts in the Brazilian Western Amazon (10). Those species were found in all study areas and in all habitat strata, showing that Leptospira could be widely distributed. All of the 23 mammal species have a known geographic distribution in the Amazon $(32,33)$. Considering the 16 PCR positive species, the most tolerant species are often found in peri-urban and rural forest fragments, and therefore, the most
TABLE 2 | Generalized linear models (GLM) for the prevalence of infection by Leptospira sp. in small mammals from Western Amazon, Acre, Brazil.

\begin{tabular}{lccccc}
\hline Models & AICc & Delta & Weight & K & Log-Likelihood \\
\hline Locality & 141.5 & 0 & 0.374 & 4 & -66.535 \\
Null & 142 & 0.54 & 0.285 & 1 & -69.993 \\
\hline
\end{tabular}

AlCc, corrected version of Akaike information criterion; Delta, Difference between the AlCc value of a model and that of the best model; Weight, Akaike weights; K, number of parameters of the model.

in contact with humans are the marsupials, D. marsupialis and P. canus, and rodent species Proechimys gardneri (32). Regarding other carrier/host species, besides their potential role in the Leptospira transmission in the Amazon region, some of them could also have an epidemiological importance in other Brazilian regions since they have a wider geographic distribution.

Moreover, genetic analysis showed that Leptospira species are circulating in different ecosystems including humans and other animals as carrier/hosts. This finding confirms the importance of a One Health context to study leptospirosis. Finally, this study reports the first evidence of the diversity of small mammals as leptospiral carriers/hosts in the western Brazilian Amazon forest.

\section{DATA AVAILABILITY STATEMENT}

All datasets generated for this study are included in the article/Supplementary Material.

\section{ETHICS STATEMENT}

The animal study was reviewed and approved by The following licenses were used to conduct the study: permanent license to collect zoological material number 13373 (SISBIO-ICMBIO) and CEUA LW-39/14 license (Ethics Committee on animal useFIOCRUZ).

\section{AUTHOR CONTRIBUTIONS}

LM paper writing, animal sampling, field work, PCR and MAT laboratory procedures, and project coordination. SB paper writing, bibliography research, field work, animal sampling, and data analysis. MD Leptospira sequencing, phylogenetic analysis, figures development, and paper writing. RP paper writing, bibliography research, and data analysis. NdA paper writing, field work, animal sampling, PCR procedures, and data analysis. PD'A paper writing, field work, animal sampling, animal identification by karyotyping, and DNA sequencing. AB paper writing, animal sampling, field work, animal identification by external, and cranial morphology. CC paper writing, field work, animal sampling, animal identification by external, and cranial morphology. AV PCR procedures, analysis, and paper writing. GM serological procedures, analysis, and paper writing. BT paper writing, animal identification by karyotyping, DNA sequencing, and statistical analysis. FC-C leptospira sequencing analysis and paper writing. WL project coordination and paper writing. All authors contributed to the article and approved the submitted version. 


\section{FUNDING}

Field and lab work were supported by grants from Institutional Agreement IOC-Fiocruz/IFAC and from CNPq and FAPAC to Dr. LM (CNPq 428213/2016-2, CNPq 157533/2015-8 and PPSUS/FAPAC 001/2015), to Dr. PD'A (CNPq 439208/2018-1) to Dr. Elder Morato and to Dr. Marcus Silveira (PPBio/CNPq 457540/2012-5).

\section{ACKNOWLEDGMENTS}

We are grateful to the field team of Dr. LM (UFAC), à Instituto Federal de Educação, Ciência e Tecnologia do Acre. PPBIO/AC and LABPMR/Fiocruz, especially Sócrates Fraga da Costa Neto,

\section{REFERENCES}

1. Schneider MC, Najera P, Pereira MM, Machado G, Anjos CB, Rodrigues RO, et al. Leptospirosis in Rio Grande do Sul, Brazil : an ecosystem approach in the animal-human interface. PLoS Negl Trop Dis. (2015) 9:e0004095. doi: 10.1371/journal.pntd.0004095

2. Ellis WA. Animal leptospirosis. Curr Top Microbiol Immunol. (2015) 387:99137. doi: 10.1007/978-3-662-45059-8_6

3. Haake DA. Molecular epidemiology of leptospirosis in the Amazon. PLoS Med. (2006) 3:e302. 10.1371/journal.pmed.0030302

4. Matthias MA, Ricaldi JN, Cespedes M, Diaz MM, Galloway RL. Human leptospirosis caused by a new, antigenically unique leptospira associated with a rattus species reservoir in the peruvian amazon. PLoS Negl Trop Dis. (2008) 2:e213. doi: 10.1371/journal.pntd.0000213

5. Guedes IB, Araújo SAA, de Souza GO, de Souza Silva SO, Taniwaki SA, Cortez A, et al. Circulating Leptospira species identified in cattle of the Brazilian Amazon. Acta Trop. (2019) 191:212-6. doi: 10.1016/j.actatropica.2019.01.011

6. Benavidez KM, Guerra T, Torres M, Rodriguez D, Veech JA, Hahn D, et al. The prevalence of Leptospira among invasive small mammals on Puerto Rican cattle farms. PLoS Negl Trop Dis. (2019) 13:e0007236. doi: 10.1371/journal.pntd.0007236

7. Ospina-Pinto C, Rincón-Pardo M, Soler-Tovar D, HernándezRodríguez P. Papel de los roedores en la transmission de Leptospira spp. en granjas porcinas. [The role of rodents in the transmission of Leptospira spp. in swine farms]. Rev Salud Publica (Bogota). (2017) 19:555-61. doi: 10.15446/rsap.v19n4.41626

8. Venter O, Fuller RA, Segan DB, Carwardine J, Brooks T, Butchart SHM, et al. Targeting global protected area expansion for imperilled biodiversity. PLoS Biol. (2014) 12:e1001891. doi: 10.1371/journal.pbio.1001891

9. Obiegala A, Woll D, Karnath C, Silaghi C, Schex S, Eßbauer S, et al. Prevalence and Genotype Allocation of Pathogenic Leptospira Species in Small Mammals from Various Habitat Types in Germany. PLoS Negl Trop Dis. (2016) 10:e0004501. doi: 10.1371/journal.pntd.0004501

10. Vieira AS, Pinto PS, Lilenbaum W. A systematic review of leptospirosis on wild animals in Latin America. Trop Anim Health Pro. (2017) 1125:110. doi: 10.1007/s11250-017-1429-y

11. Mesquita GSS, Rocha KS, Monteiro TRM, Rosário MKSD, Baia IWM, Pereira HS, et al. Detection of antibodies against Leptospira spp. in free-living marsupials caught in the Eastern Amazon. Rev Soc Bras Med Trop. (2018) 51:368-71. doi: 10.1590/0037-8682-0236-2017

12. dos Santos LF, Guimarães MF, de Souza GO, da Silva IWG, Santos JR, Azevedo SS, et al. Seroepidemiological survey on Leptospira spp. infection in wild and domestic mammals in two distinct areas of the semi-arid region of northeastern Brazil. Trop Anim Health Prod. (2017) 49:171522. doi: 10.1007/s11250-017-1382-9

13. Vieira AS, Di Azevedo MIN, D’Andrea PS, do Val Vilela R, Lilenbaum W. Neotropical wild rodents Akodon and Oligoryzomys (Cricetidae: Sigmodontinae) as important carriers of pathogenic
Camila dos Santos Lucio and Fernando de Oliveira Santos for help in fieldwork. We are grateful to Drs. Thomas Wittum, Dixie Mollenkopf, Gregory Ballash, and Elizabeth Parker for the technical and English review and to the three referees for their helpful comments. We also thank UFAC for conceding the PIBIC scholarships. MD is a FAPERJ fellow. WL and PSA are CNPq fellows.

\section{SUPPLEMENTARY MATERIAL}

The Supplementary Material for this article can be found online at: https://www.frontiersin.org/articles/10.3389/fvets. 2020.569004/full\#supplementary-material renal Leptospira in the Atlantic forest, in Brazil. Res Vet Sci. (2019) 124:280-3. doi: 10.1016/j.rvsc.2019.04.001

14. Jorge S, Hartleben CP, Seixas FK, Coimbra MA, Stark CB, Larrondo AG, et al. Leptospira borgpetersenii from free-living white-eared opossum (Didelphis albiventris): first isolation in Brazil. Acta Trop. (2012) 124:14751. doi: 10.1016/j.actatropica.2012.07.009

15. Fornazari F, Langoni H, Marson PM, Nóbrega DB, Teixeira CR. Leptospira reservoirs among wildlife in Brazil: Beyond rodents. Acta Trop. (2018) 178:205-12. doi: 10.1016/j.actatropica.2017.11.019

16. Lemos ERS, D'Andrea PS. Trabalho de Campo Com Animais: Procedimentos, Riscos e Biossegurança. Rio de Janeiro, Publisher: FIOCRUZ, Rio de Janeiro, RJ, Brazil. (2014). p. 180.

17. Bonvicino CR, Otazu IB, Vilela JF. Karyologic and molecular analysis of Proechimys Allen, 1899 (Rodentia, Echimyidae) from the Amazonian region. Arq Mus Nac. (2005) 63:191-200.

18. Gonçalves PR, Oliveira JA. An integrative appraisal of the diversification in the Atlantic Forest genus Delomys (Rodentia: Cricetidae: Sigmodontinae) with the description of a new species. Zootaxa. (2014) 1:1-38. doi: 10.11646/zootaxa.3760.1.1

19. Chakraborty A, Miyahara S, Villanueva SY, Saito M, Gloriani NG, Yoshida S. A novel combination of selective agents for isolation of Leptospira species. Microbiol Immunol. (2011) 55:494-501. doi: 10.1111/j.1348-0421.2011. 00347

20. World Organisation for Animal Health, 2012: Leptospirosis. In: Manual of Diagnostic Tests and Vacines for Terrestrial Animals. World Organization for Animal Health, Paris. Available online at: http://www.oie.int/fileadmin/ Home/eng/Health_standards/tahm/3.01.12_LEPTO.pdf

21. Vieira AS, Narduche L, Martins G, Schabib PIA, Zimmermann NP, Juliano RS, et al. Detection of wild animals as carriers of Leptospira by PCR in the Pantanal biome, Brazil. Acta Tropica. (2016) 163:879. doi: 10.1016/j.actatropica.2016.08.001

22. Thompson J, Higgins D, Gibson, T. CLUSTAL W: improving the sensitivity of progressive multiple sequence alignment through sequence weighting, positions-specific gap penalties and weight matrix choice. Nuc Ac Res. (1994) 22:4673-80.

23. Hall TA. BioEdit: a user-friendly biological sequence alignment editor and analysis program for Window 95/98/NT. Nucleic Acids Symposium Series. (1999) 41:95-8.

24. Kumar S, Stecher G, Li M, Knyaz C, Tamura K. MEGA X: molecular evolutionary genetics analysis across computing platforms. Mol Biol Evol. (2018) 35:1547-9. doi: 10.1093/molbev/msy096

25. R Core Team. $R$ : A Language and Environment for Statistical Computing. $R$ Foundation for Statistical Computing, Vienna, Austria. (Retrieved on February 10th, 2017 (2017). Available from: https://www.R-project.org/

26. Oksanen J, Blanchet FG, Kindt R, Legendre P, Minchin PR, O’Hara RB, et al. Community Ecology Package. (2017) R. package version. 2, 4-2.

27. de Albuquerque NF, Martins G, Medeiros L, Lilenbaum W, Ribeiro VMF. The role of capybaras as carriers of leptospires in periurban 
and rural areas in the western Amazon. Acta Trop. (2017) 169:5761. doi: 10.1016/j.actatropica.2017.01.018

28. Faine S, Adler B, Bolin C, Perolat P. Leptospira and Leptospirosis. (2 ${ }^{\text {nd }}$ ed). Melbourne, VIC: MedScience (2000). p. 272.

29. Bunnell JE, Hice CL, Watts VM, Montrueil V, Tesh RB, Vinetz, et al. Detection of pathogenic Leptospira spp. Infections among mammals captured in the Peruvian Amazon basin region. Am J Trop Med Hyg. (2000) 63:2558. doi: 10.4269/ajtmh.2000.63.255

30. Cortez V, Canal E, Dupont-Turkowsky JC, Quevedo T, Albujar C, Chang TC, et al. Identification of Leptospira and Bartonella among rodents collected across a habitat disturbance gradient along the Inter- Oceanic Highway in the southern Amazon Basin of Peru. PLoS ONE. (2018) 13:e0205068. doi: 10.1371/journal.pone.0205068

31. Fischer S, Mayer-Scholl A, Imholt C, Spierling NG, Heuser E, Schmidt $\mathrm{S}$, et al. Leptospira genomospecies and sequence type prevalence in small mammal populations in Germany. Vect Borne Zoonotic Dis. (2018) 4:188-99. doi: $10.1089 / v b z .2017 .2140$

32. Faria MB, Lanes RO, Bonvicino CR. Marsupiais do Brasil. Guia de identificação com base em caracteres morfológicos externos e cranianos. 1. ed. São Caetano do Sul: Amélie Editorial (2019). v. 1. p.84.

33. Patton JL, Pardiñas UFJ, D'Elía G (editors). Mammals of South America. Volume 2: Rodents. Chicago, IL: University of Chicago Press (2015). p. xxvi +1336 .

Conflict of Interest: The authors declare that the research was conducted in the absence of any commercial or financial relationships that could be construed as a potential conflict of interest.

Copyright (C) 2020 Medeiros, Braga Domingos, Azevedo, Peruquetti, de Albuquerque, D'Andrea, Botelho, Crisóstomo, Vieira, Martins, Teixeira, Carvalho-Costa and Lilenbaum. This is an open-access article distributed under the terms of the Creative Commons Attribution License (CC BY). The use, distribution or reproduction in other forums is permitted, provided the original author(s) and the copyright owner(s) are credited and that the original publication in this journal is cited, in accordance with accepted academic practice. No use, distribution or reproduction is permitted which does not comply with these terms. 